Journal Home Page:

http://perlinguam.journals.ac.za

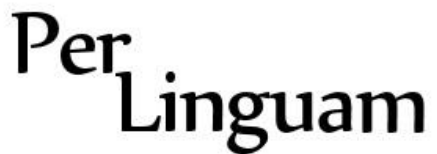

A Journal for Language Learning Tydskrif vir Taalaanleer

\title{
LITERAY FOR ALL? USING MULTILINGUAL READING STORIES FOR LITERACY DEVELOPMENT IN A GRADE ONE CLASSROOM IN THE WESTERN CAPE
}

Ancyfrida Prosper, Open University of Tanzania

Vuyokazi Nomlomo, University of the Western Cape

This paper reports on a literacy pilot project which investigated the use of multilingual reading books and the pedagogical strategies that were employed by one bilingual teacher and her assistant to teach literacy in a linguistically diverse Grade 1 classroom in a primary school in the Western Cape, South Africa. Data were collected by means of classroom observations and semistructured interviews to understand the teacher's literacy instruction, reflecting her understanding of the multilingual pedagogical approach as a means of fostering learners' biliteracy skills. Through the lens of the social constructivist theory and the notion of biliteracy, this paper argues that bilingual competence does not necessarily translate to biliteracy if the teaching approaches and learning materials are not systematically and adequately used to support learners ' listening, oral, reading and writing skills in different languages in an integrated and holistic manner in multilingual classrooms. It concludes that, despite the progressive South African Language-inEducation Policy which supports additive multilingualism, classroom practices continue to reinforce monolingualism in English, which deprives the majority of learners of meaningful access to literacy in different languages as they do not exploit the socio-cultural and cognitive capital embedded in the learners' home languages for additive bilingual and biliteracy competence.

\section{Keywords}

Literacy; biliteracy; multilingual pedagogical approach; Foundation Phase; bilingualism

\section{INTRODUCTION}

Many countries across the globe are experiencing an increase in linguistic diversity due to immigration, conflicts and wars, especially in Africa (Chumbow, 2013). Immigrant children who speak different languages constitute more than half of the student population in many schools in Europe (Kerfoot \& Simon-Vandenbergen, 2015). As a result, in many countries both in the North and South, multilingualism has become a norm (Snow, 2014). While multilingualism is regarded as a linguistic and educational resource (Chumbow, 2013), recent research shows that it is also an educational challenge for children who start schooling in languages other than their home languages (such as English and French), both in countries in the North and in the South (Dubeck, Jukes \& Okello, 2012; Glanz, 2013; Gove \& Cvelich, 2010; Kerfoot \& Simon-Vandenbergen, 2015; McIIwraith, 2013; Roskos et al., 2003; Ruedo, 2002; Snow, 2014; UNESCO, 2006). These children struggle to master the basic skills of reading and writing in a second language (Bloch, 2006; Gove \& Cvelich, 2010; Kirkpatrick, 2013; O’Carrol \& Hickman, 2012; UNESCO, 2006), and often lag behind their counterparts who learn literacy through the medium of their home 
languages when they start schooling. Such literacy deficiency often spills over to higher grades and in higher education (Samuels, 2013), especially in poor and disadvantaged areas with insufficient teaching and learning resources (August, 2006; Chisholm, 2004; Jansen, 2008; Ruedo, 2002). Additionally, poor teacher training and teachers' lack of cross-cultural competence and proficiency in their learners' home languages are regarded as some of the factors that negatively impact on learners' acquisition of biliteracy skills in many multilingual classrooms across the globe (August, 2006; Baker, 2006; Cummins et al., 2005; Gove \& Cvelich, 2010; Ruedo, 2002).

In relation to the above, multilingualism in South African education has received much attention over the past two decades as part of the inclusive and progressive Language-in-Education Policy with eleven official languages (Department of Education, 1997). The Language-in-Education Policy advocates the maintenance of learners' home languages by promoting additive bi- or multilingualism in education. However, it appears that the country is still experiencing challenges with regard to proper implementation of multilingual practices in schools (Bloch, 2005). The common barriers that have been identified include the lack of multilingual materials, particularly reading books in African languages, and lack of teachers' competence in these languages (Bloch, 1996, 2000, 2005, 2006). For example, the findings of previous studies conducted in some Cape Town primary schools with Afrikaans- and English-speaking children (Bloch, 1996, 2005, 2006; Prinsloo, 2008; Prinsloo \& Stein, 2004) mentioned lack of multilingual materials in schools as the main barrier to learners' multilingual literacies. This often results in unequal opportunities of learners' epistemological access to learning, especially in classrooms where children start reading and writing in a second or third language (O'Carrol \& Hickman, 2012). The findings of these studies prompted us to investigate how teachers took advantage of the Kagiso multilingual story books that were supplied by the Western Cape Education Department (WCED) as part of the Literacy for All pilot project which aimed to support literacy instruction and to promote multilingualism and biliteracy in the Foundation Phase (Grades R-3). Additionally, the research was based on our assumption that there was a lack of understanding of multilingual and biliteracy pedagogical approaches in many South African classrooms that have children from diverse linguistic backgrounds.

In light of the above, this article reports on the implementation of a multilingual literacy pilot programme in one primary school in Cape Town, South Africa, through the use of story books in different languages (namely, Afrikaans, English and isiXhosa) in a linguistically diverse Grade 1 classroom where the main language of instruction was English. The study on which this article is based sought to investigate whether the multilingual story books were used purposefully and effectively to facilitate learners' reading and writing in the three languages and to enhance their biliteracy or multilingual literacy competence. Guided by our understanding of the social constructivist view of learning (Palincsar, 1998) and the relevance of multilingual pedagogical approaches in supporting learners' biliteracy skills (Bloch, 2006; Haukåsa, 2015; Hornberger, 2004; Street, 2000), we explored the reciprocal relationship between language development and early literacy development (Kennedy et al., 2012). This entailed observing how the multilingual reading books in the learners' languages were used for literacy instruction to enhance young learners' emergent and conventional literacy skills (Kennedy et al., 2012) in a linguistically diverse classroom. We were also influenced by our understanding that children learn better when they read stories in a familiar language (August, 2006), as home language literacy skills can be transferred 
to additional language and literacy learning (Baker, 2006; Cummins et al., 2005; Street, 1995). This article was guided by the following research questions:

(i) How were reading stories in the learners' home languages used in a Grade 1 multilingual classroom?

(ii) What were the limitations of storytelling with regard to Grade 1 learners' biliteracy development?

In the following section, we provide a framework that unpacks the key concepts and theories that pertain to multilingualism and biliteracy as socio-cultural constructs. The discussion highlights the relationship between bilingualism and biliteracy, and the relevance of these concepts in linguistically diverse classrooms. This is followed by a discussion of a research methodology framework, which leads to the findings that relate to the research questions mentioned above.

\section{THEORETICAL FRAMEWORK}

This article is framed within literature and theories on literacy, bilingualism, biliteracy and multilingualism in order to illuminate the socio-cultural relationship between these concepts and their relevance to literacy development in multilingual contexts (Chumbow, 2013; Hornberger, 2004; Martin-Jones \& Jones, 2000; Street, 2000). It also makes reference to the multilingual pedagogical approach (Haukåsa, 2015) to understand teacher-learner interactions in culturally and linguistically diverse teaching and learning environments. As a point of departure, we provide a brief definition of literacy to illuminate the connection between bilingualism and biliteracy.

Literacy is defined within a particular socio-cultural context in which practices and events take place (Barton \& Hamilton, 1998; Baynham, 1995; Gee, 1996; Street, 1993, 2001). This definition recognises the linguistic and cultural resources that learners bring to the classroom, thus reinforcing the notion of literacy as a social practice (Street, 2001). The home literacies embedded in the learners' home languages facilitate the flow of knowledge and connect the home and school literacies that validate the learners' identities, as well as their linguistic and cultural capital in multilingual settings (Cummins et al., 2005). They are also useful in the acquisition of second language literacy (Baker, 2006; Street, 1995), and they are regarded as cognitive and socio-cultural resources on which individuals draw as they negotiate identities in different domains of their lives (Hornberger, 2004; Martin-Jones \& Jones, 2000; Street, 1984, 2000).

Research shows that proficiency in the home language facilitates concept development in a new language, and that language skills transfer between languages (Giambo \& Szecsi, 2015; Reyes, 2006). If the home language is well developed and supported, strong language skills and academic concepts are likely to be achieved in both languages, which results in bilingualism, i.e., competence in two languages (Giambo \& Szecsi, 2015). It is argued that bilinguals as young as two years of age have stronger cognitive control in learning than monolinguals (Giambo \& Szecsi, 2015). This observation challenges the deficit view that the learners' home languages interfere with the acquisition of a new language, which often leads to the exclusion of the learners' home languages in multilingual classrooms (Burcu et al., 2014; Giambo \& Szecsi, 2015). On the contrary, bilingual practices affirm and maintain the learners' home languages. In this way, the additive perspective of the linguistic and cognitive value of the learners' home languages is supported in the classroom (Burcu et al., 2014; Reyes, 2006). 
Bilingual competence is not synonymous with biliteracy, although there is a close relationship between the two concepts. Language and literacy competence in one language facilitates literacy development in another language. This occurs as bilinguals learn to read and write in two languages, which may occur simultaneously or sequentially, and to varying degrees of competence such as receptive-to-productive or oral-to-written skills (Giambo \& Szecsi, 2015; Hornberger, 2004; Reyes, 2006). Bilingual children are able to transfer home language literacy skills such as decoding and phonological awareness to the other language, especially if the two languages have similar writing systems (Giambo \& Szecsi, 2015; Reyes, 2006). In other words, strong language skills in two languages benefit bilingual children in numerous ways, such as word recognition, vocabulary, listening comprehension, reading and writing strategies, especially spelling if children are afforded access to and opportunities to use both languages in the classroom (Giambo \& Szecsi, 2015; Reyes, 2006). In this way, bilingual children become biliterate rather than literate in the dominant language only, and they develop abilities to draw on the two languages as linguistic and cognitive resources (Reyes, 2006). So biliteracy is the ability to read and write in two languages (Reyes, 2006).

In linguistically diverse South African classrooms, the relevance and significance of biliteracy, both for teachers and learners, cannot be underestimated as it recognises the value of the home language in literacy instruction and development. In fact, it is the cornerstone of multilingualism as it acknowledges the presence and use of several languages in various forms and domains (Burcu et al., 2014). Educationally, multilingualism and biliteracy are perceived as an appropriate conceptual framework to understand research in teaching and language planning in linguistically diverse contexts (Chumbow, 2013; Hornberger, 2004). Hence, Haukåsa (2015) refers to multilingual pedagogy as a means of accommodating cultural and linguistic diversity in teaching and learning.

The principles of the multilingual pedagogical approach recognise the social and cognitive aspects of learning as they foreground the value of the learners' home language in learning additional languages (Haukåsa, 2015). Given the interconnectedness between language proficiency and literacy development (Giambo \& Szecsi, 2015), the multilingual pedagogy pays attention to the range of literacies possessed by learners (Burcu et al., 2014). It requires competent teachers who should be multilingual themselves and understand learners' linguistic, cognitive and affective differences and their influence in knowledge construction (Bruning et al., 1999; Haukåsa, 2015; Ohta, 2000; Yilmaz, 2008). In classrooms where teachers do not know the multiple languages spoken by the learners, it may be problematic to fully explore strategies to facilitate learners' equal access to learning (Turner \& Youb, 2005). In such cases, the learners' home languages may be perceived as deficits that hinder the acquisition of the dominant language (Bloch, 1996; O'Carrol \& Hickman, 2012).

In this article, we refer synonymously to multiple literacies and biliteracy to understand the teacher's and learners' language (oral, reading and writing) competences in the different languages spoken in the classroom. We also use these concepts to understand the learners' different identities and how they impact on learners' reading and writing across the different languages (Chumbow, 2013; Hornberger, 2004). Guided by the notion of literacy as a sociocultural practice (Street, 2000), we believe that children start schooling with a linguistic and cultural capital (i.e., the home languages) that could be exploited as a valuable asset to multiple literacies. Thus, our study aimed 
to uncover literacy instructional practices in the Grade 1 multilingual classroom in order to gain an insight into whether the Kagiso multilingual reading books were effectively used to enhance learners' multilingualism and biliteracy development. We explored teacher-learner interaction in relation to the principles of multilingual pedagogy to understand whether the teaching strategies provided learners access to biliteracy in a manner that acknowledged their home language proficiency as they developed early conventional reading and writing.

\section{RESEARCH METHODOLOGY}

This study employed a qualitative research design. Data collection comprised classroom observations and a semi-structured interview with both the Grade 1 teacher and her assistant. The use of the two methods of data collection aimed at increasing the chances of credibility of the research findings (Babbie \& Mouton, 2001: 20) instead of relying on one method of data collection.

In this section, we focus on the research site that was used as a source of data, as well as sampling, research procedures and ethical considerations that were observed during data collection.

\section{Research site}

This study was conducted in one primary school in the Western Cape. Established in 1933 to cater for white children only, this school opened doors to other racial groups after 1994. At the time of data collection in 2012, the school had a total enrolment of 364 culturally and linguistically diverse learners (from Grade 1 to 7), and 10 teachers. There was one Grade 1 class with a total of 40 learners of the average age of seven years: 18 boys and 22 girls. Learners came from different South African language groups, namely, isiXhosa, Afrikaans, English and Setswana. Of the 40 learners, 17 were home language speakers of isiXhosa, while 12 spoke Afrikaans as a home language. There were only six English home language speakers. There was one home language speaker from each of these languages: Setswana, French, Lingala, Shona and Kirundi. The medium of instruction in the school was English from Grade 1 to Grade 7.

\section{Sampling and participants}

The study employed a purposeful and convenient sampling which involved a Grade 1 teacher and her assistant, and the whole Grade 1 class. The teacher and her assistant were the only people who could participate in the research study as the school had one Grade 1 class only. The school was chosen on the basis that it participated in the Literacy for All project of the WCED. In order to support the WCED literacy pilot project, teacher assistants were appointed for the Foundation Phase (Grades 1-3). Their role involved administrative work and assisting learners with reading. Another criterion that was used to conduct research in this school was the fact that its learner population was culturally and linguistically diverse, and the school was easily accessible to learners from the neighbouring black townships of Cape Town. As a result, isiXhosa speaking learners from these townships have been admitted in big numbers in this school since it opened its doors to other racial groups after 1994. Additionally, it accommodates learners from other African countries (such as Zimbabwe and Congo) who live in nearby townships, and who speak other African languages. 
The class teacher, who was in her late thirties, spoke Afrikaans as her home language. She was bilingual in English and Afrikaans. At the time of data collection, she had 19 years of teaching experience and her specialisation was English language teaching for lower primary classrooms. The teacher assistant was in her early twenties, without a tertiary qualification or professional training as a teacher. She was a home language speaker of isiXhosa and was competent in English (L2). During the data collection period, she had two years of experience as an assistant in the Grade 1 classroom.

\section{Procedure}

Observations in the Grade 1 classroom took approximately five months spread over the second and third terms of the school calendar in 2012. The Grade 1 teacher and her assistant were observed in their interaction with the learners in literacy lessons. The main aim was to investigate how the teacher and her assistant made use of the multilingual reading books to teach literacy to young learners speaking different languages. The observation targeted literacy lessons only and how the various literacy aspects such as reading, writing, vocabulary development and comprehension were promoted in languages other than English to promote learners' biliteracy through the use of the Kagiso multilingual story books. In other words, the investigation sought to determine whether the story books were purposefully and effectively used. The Kagiso stories are the same in all languages as they have been translated into different South African languages. They are developed in such a way that learners are introduced to different stories sequentially to foster their understanding. The stories begin with simple words and sentences, with few characters. The illustrations used in the story books portray real life in the township, such as shopping, playing with friends, dogs, etc.

Learners were observed in their reading and writing activities in order to establish whether they were supported to develop multilingual literacies in reading and writing across the three languages. In total, 17 Grade 1 literacy lessons were observed over two school terms. All 17 lessons that were observed were tape recorded. The lessons covered a range of areas, such as reading, listening, reading comprehension and writing. Some of the lessons were based on phonics, vocabulary development, sentence construction and writing activities, which included spelling. With the permission of all the participants in the study, six of the lessons were video recorded in order to capture the authenticity of classroom practices. This was done randomly and the convenience of the teacher and researchers.

Literacy tasks that followed story reading in the three languages formed part of the observations. Some of the tasks were written, while others were oral and were used to assess the learners' listening skills and comprehension of the stories, as well as their knowledge and understanding of letters and sounds in English. Additionally, the lessons captured teacher-learner interactions, which were analysed for the purpose of the study.

We also focused on the teaching strategies that were used by the teacher and her assistant to enhance learners' biliteracy skills. In other words, we observed how Afrikaans and isiXhosa were used to support learners' reading and writing in two or more languages, including English, which was the main language of instruction in the school. The observed literacy lessons took approximately 35 to 45 minutes each. Field notes were also taken in order to capture literacy 
actions and events in the classroom, and at the school at large. This was useful to provide a rich description of data at the end (Henning et al., 2004: 7).

Semi-structured interviews were used to probe further about the teacher's strategies and beliefs in developing learners' multiple literacies. The interviews were used to complement observation data, and to understand and verify certain issues relating to literacy teaching. The teacher assistant was also interviewed about her role in the Grade 1 classroom. The semi-structured interviews were recorded to maintain accuracy of the data that were subsequently transcribed and coded for analysis purposes.

\section{Ethical considerations}

The research study adhered to ethics with regard to the participants' confidentiality, respect and voluntary participation (De Vos et al., 2005; Henning et al., 2004). Permission to participate in the study was sought from the different participants, including parents, teachers and the WCED. Full information about the aims and scope of the research study was shared with the participants.

Before commencing with data collection, consent letters to participate in the study were received from the different participants, including the WCED, school principal, Grade 1 teacher, teacher assistant and parents. As the study involved young children, we were guided by Schenk's and Williamson's (2005) principles of ensuring that every child's autonomy was respected and that the research activities did not subject the children to harm and distress. We also ensured that their identity was protected, and we were sensitive to their classroom needs and behaviour. Our observations did not interrupt normal classroom practices. Ethical clearance from the higher education institution where one of the researchers was registered was obtained.

The collected data were transcribed to facilitate data analysis. We analysed the data thematically by sorting data into different broad themes (Dainte \& Lightfoot, 2004: 225) which aligned with the aims and research questions that underpinned the study. The two broad themes that emerged from data analysis pertained to pedagogical strategies that the teacher employed to facilitate reading and storytelling in different languages, including the learners' home languages, as well as the limitations of storytelling with regard to the development of learners' biliteracy and multilingual competences.

\section{RESEARCH FINDINGS}

In the section that follows, we present the findings in relation to the research questions that guided this article, namely, how the story books in different languages were used and the limitations thereof with regard to biliteracy development. The findings we present here relate only to the observation data and teacher interviews, and they address the research questions that underpinned the study. The sub-headings or categories in which they are presented relate to the pedagogical strategies that were used by the teacher and her assistant to enhance reading in the three different languages in the Grade 1 classroom. They also highlight the limitations that were observed in the use of the multilingual reading books for literacy development in three languages (Afrikaans, English and isiXhosa). The first sub-heading or category relates to the pedagogical strategies that were employed by the teacher to accommodate the use of the learners' home languages in story reading. In the second and third categories, we highlight the limitations of the use of the Kagiso multilingual books for biliteracy development in Grade 1.

Per Linguam 2016 32(3):79-94

http://dx.doi.org/10.5785/32-3-622 
The findings indicate that there were more pedagogical limitations than benefits of using the multilingual story books. For example, both observation and interview data showed that the use of the stories in the learners' home languages was a useful cognitive resource to learners in terms of enhancing their comprehension of stories in English. However, the teacher's pedagogical strategies seemed to limit learners' access to other languages in the form of reading and writing, as all literacy tasks were conducted in English only. It also appeared that the teacher and her assistant were not properly prepared to teach literacy across languages. In the following discussion, details pertaining to the above observations are provided.

\section{Cognitive benefits of home language reading stories}

Classroom observation data indicated that some efforts were made by the teacher to encourage multilingualism by reading stories in the three languages. The Grade 1 teacher, who was bilingual in Afrikaans and English, had good teaching experience. Her teaching strategies showed her familiarity with and knowledge about literacy teaching approaches. She followed the Curriculum Assessment Policy Statement (CAPS) which outlines literacy teaching strategies (Department of Basic Education, 2012). She recognised the importance of storytelling and reading as key components of literacy.

The teacher assistant read the stories in isiXhosa and later explained in English. She served as a mediator between the teacher and learners because she read to the learners in isiXhosa and in English. This was helpful to learners as they were supported to understand the stories in their home languages before they were read to the learners in English (L2). The class teacher did the same in Afrikaans. The Grade 1 teacher's understanding of the importance of using the learners' home languages was apparent, as she had this to say in the interview:

I find that it is important for the learner to first understand the story in his or her mother tongue, so that helps, so the translator or the teacher assistant, she will then read the story to them in isiXhosa and then what I will do is I will follow up and reading the story in English and once there, in their reading ability groups they will then come to the mat and read the book in English.

The Grade 1 teacher expressed a similar view with regard to the role of the learners' home language in supporting learners' understanding of the stories in English (L2). The teacher's view seemed to suggest that she was aware of cognitive benefits of the learners' home languages in literacy learning. She had this to say:

I think the most important role for me at the moment is for her (teacher assistant) to translate, like I said many of my learners... come from isiXhosa background so it's important for them to first understand the content or the context in their mother tongue before they can even understand or begin to grasp the concept in English.

Both the teacher's and the assistant's pedagogical strategies promoted learners' comprehension skills by asking learners to listen to stories read in their home languages. So the multilingual reading books were useful resources in facilitating learners' understanding of the stories in familiar languages, that is, their home languages. 
In relation to the above, Gibbons (2002: 36) states that, in cases where the teacher does not speak the learners' home language, a teacher assistant may be used as a resource. According to Baker (2006: 300), teacher assistants may work with small groups and help slow learners. They may sometimes translate, interpret and create classroom materials (Baker, 2006). The use of teacher assistants who have competence in the learners' home languages is likely to create a bilingual or multilingual environment and it also mediates new knowledge between the teacher and learners (Culican et al., 2006: 8). The role of the bilingual teacher assistant in the Grade 1 classroom was valuable.

\section{Limitations of the monolingual literacy approach}

The presence of the teacher assistant made a difference with regard to introducing stories in the learners' home languages as a bridge to English (L2) literacy, but we observed that there were limitations to this practice. As stated above, the Grade 1 teacher was bilingual in English and Afrikaans while her assistant had bilingual competence in English and isiXhosa. Their teaching strategies seemed to reinforce subtractive bilingualism or monolingualism in English (L2) literacy only, instead of fostering biliteracy or multiple literacies. The two languages (Afrikaans and isiXhosa) were listened to only, and were not used in oral, reading and writing activities to enhance learners' multilingual skills across the three languages. The learners were not encouraged and supported to speak, read and write in other languages. In other words, there was no integration of listening, oral, reading and writing skills to enhance learners' access to isiXhosa and Afrikaans literacy. This suggests that other languages, namely, Afrikaans and isiXhosa, were not fully exploited as linguistic resources to facilitate learners' reading and writing skills. The observation data showed that, when the two languages were used in reading, the learners were just passive listeners as they were not afforded opportunities to read the stories on their own and to engage with texts in reading and writing in their home languages.

Although the texts were read to learners in the three languages, the stories were explained to the learners in English only. Consolidation and assessment of the literacy lessons were also done in English only. Although the reading of stories in the learners' home languages served as a scaffold to learners' comprehension of the stories in English (L2), it appeared to reinforce the high status of English in the classroom, instead of supporting the use of other languages in literacy activities. This finding is consistent with the common myth that, if young children learn to read and write in their home languages and in the additional language simultaneously, they may be confused (Bloch, 2006). It is common practice in many multilingual classrooms that teachers focus on English (L2) literacy only, and ignore the learners' home languages in teaching reading and writing (Bloch, 2006; O’Carrol \& Hickman, 2012).

While the role played by the Grade 1 teacher and her assistant in fostering the visibility of isiXhosa and Afrikaans in the English medium classroom through story reading cannot be undermined, the practice did not seem to support learners' access to other languages in the form of speech, reading and writing, which are key components of literacy development. Other languages (Setswana, French, Lingala, Shona and Kirundi) that were spoken by few learners were absolutely invisible in the Grade 1 classroom. Their invisibility could be attributed to two factors. Firstly, their speakers were in minority in terms of numbers compared to Afrikaans, English and isiXhosa speakers. Secondly, both the teachers and the learners had no competence in them as they were foreign languages spoken in other African countries, except Setswana. Given this, it may be argued that 
the speakers of these languages did not get equal support opportunities to literacy learning like their Afrikaans and isiXhosa counterparts whose languages were used to mediate story comprehension in English (L2). This observation seems to correspond with Turner and Youb's (2005) claim that it may be a challenge to facilitate learners' equal access to learning in classrooms where teachers are not competent in the multiple languages spoken by their learners.

In light of the above, the teacher's literacy practice contradicted the belief that early literacy development in the second language is enhanced if oral proficiency in the home language is supported (Bloch, 2006; O'Carrol \& Hickman, 2012). It was also not compatible with the view that learners learn to read and write easily in their home languages because home language literacy skills can be transferred across languages (Gove \& Cvelich, 2010; Ruedo, 2002; UNESCO, 2006). This often happens in cases where there is a mismatch between the learners' home languages and the languages used for teaching and learning (Gove \& Cvelich, 2010:18), as teachers tend to pay more attention to literacy development in the language used as the main medium of instruction.

\section{Improper planning and inadequate teacher training}

The study data showed that, while an effort was made by the WCED to supply the school with multilingual reading books, there seemed to be no proper planning and adequate teacher training for the implementation of multilingualism for literacy development in the school. The interview data revealed that the teacher was not properly prepared to implement multilingual approaches for linguistically diverse classrooms. The teacher claimed that she attended one workshop that was conducted by the authors of the Kagiso multilingual books, and there were no follow-up sessions or additional support at school and district levels. The teacher assistant never had any training on literacy teaching. She relied on her own experience as a bilingual and was guided by the teacher's instructions on what to do in the classroom. The interview data also showed that the school had no formal plan to support teachers to manage multilingual classrooms. There were no additional materials in isiXhosa, except the reading books that were supplied to the school which were used for story reading only.

Another constraint was the teacher's lack of competence in the learners' languages, other than English and Afrikaans. In addition, the teacher assistant was not a trained teacher, and was not knowledgeable of the appropriate strategies of teaching reading and writing. As a result, her role was to read the stories in isiXhosa and English only, without following proper strategies of teaching reading. This observation suggests that, while cross-language transfer is viewed as a resource in multilingual classrooms, it may be a challenge where the teacher has limited or no competence in the learners' languages (Cummins et al., 2005). The observation also shows that bilingual competence does not automatically translate to proper and effective literacy instructional practice, as literacy is a complex and dynamic process (August, 2006). Literacy instruction requires deeper theoretical and pedagogical insights of language development in young children, which forms the basis of early literacy development (Nomlomo \& Desai, 2014). Therefore, an understanding of how young children learn, and the complexities of literacy acquisition, should form part of the teaching and learning process in early childhood education. This seemed not to be the case with the teacher assistant, whose literacy reading instruction was not underpinned by this kind of understanding. 


\section{Implications for biliteracy and multilingualism}

Many scholars believe that reading and writing concepts are transferred through print, and that phonological awareness and text comprehension are also facilitated through print integration in literacy teaching (Ruedo, 2002; Snow, 2014). In line with this view, Roskos et al. (2003:3) claim that the three critical contents of early literacy include oral language comprehension, phonological awareness and print knowledge.

The findings of this study show that Afrikaans and isiXhosa were used to scaffold learners' comprehension of the stories in an additional language, namely, English. This practice was relevant as comprehension is one of the integral elements of literacy (Snow, 2014), but it did not provide learners with adequate opportunities to speak, read and write in their own languages. In this way, learners were not challenged to translate their home language skills which were understandable to them (Garcia, 2009:46) to support their oral, reading and writing skills across the three languages. In other words, the pedagogical strategies simulated the learners' receptive language skills and ignored the productive skills (oral and writing) which are regarded as key elements of biliteracy development (Hornberger, 2004).

Young learners often struggle with literacy learning in an additional language if their own home languages are not fully developed to serve as an effective bridge to literacy development in an additional language (Gove \& Cvelich, 2010). From a social constructivist point of view, the study findings indicate that the teacher's instructional practices did not seem to support and exploit the linguistic and cultural capital embedded in the learners' home languages and the interdependence of language skills to enhance the young learners' biliteracy skills (Cummins et al., 2005; Edwards, 1983; Latham, 2002), despite the availability of multilingual materials in the classroom.

According to UNESCO (2006), strong multilingual programmes make use of the learners' home languages as a medium of instruction as long as possible and appropriate methodologies are used to teach other languages as additional languages. The additive multilingual approach facilitates the transfer of the home language literacy skills to the additional language (UNESCO, 2006). On the contrary, poorly planned multilingual programmes often have inadequately trained teachers, lowquality classroom materials and little time allowance to build strong literacy foundations in the learners' home languages (UNESCO, 2006). The findings of this study appear to align with the latter view.

Poor planning, teachers' language competence and the availability of suitable literacy materials for diverse learners remain common problems in the implementation of multilingual education (Ruedo, 2002). These factors influence the quality of literacy teaching and learner achievement in linguistically diverse classrooms (Gove \& Cvelich, 2010), especially where learners start schooling in an additional language. This is what Chisholm (2011) refers to as 'silent exclusion' which perpetuates children's unequal access to meaningful learning. The findings of study seem to confirm this view in that other languages were excluded in supporting the learners' multiple literacies.

\section{CONCLUSION}

The findings presented in this article cannot be generalised due to the small sample used in this study. However, the findings are useful as they provide an insight into how teachers are still Per Linguam 2016 32(3):79-94 
grappling with promoting multilingualism and biliteracy in linguistically diverse South African classrooms. They indicate that bilingual competence does not necessarily translate to biliteracy if the teaching approaches and learning materials are not systematically and adequately used to support learners' listening, oral, reading and writing skills in different languages in an integrated and holistic manner in multilingual classrooms.

This article has also shown that, whilst there is awareness about language diversity and initiatives are taken to implement multilingual practices in certain Western Cape schools through the Literacy for All project, there are still structural and pedagogical constraints that need serious attention by the government and other stakeholders. The legacy of the past discriminatory language policies still prevails, and continues to perpetuate social stratification (Makoe \& McKinney, 2014) and unequal access to learning. As alluded in Desai (2013), it is difficult to change the power dynamics in a country like South Africa which has entrenched social and economic inequalities. Thus, the government needs to play an active role in the implementation of multilingual education for multiple literacies, and ensure that schools are provided with more and appropriate multilingual resources. The success of the multilingual pedagogical approach depends largely on the multilingual competence of the teachers (Haukåsa, 2015). If the teachers are not competent in the learners' home languages, they might struggle to accommodate learners who speak other languages in their classrooms.

The government should also invest in teacher training in order to achieve the vision of 'literacy to all' and biliteracy. Teacher training should be prioritised as a means of equipping teachers with strategies on how to work with learners from different backgrounds in one classroom. Such training could entail reading and writing strategies in two or more languages to support learners' biliteracy skills, as well as developing high quality materials in different languages (Giambo \& Szecsi, 2015). Parents, pre-service teachers, qualified translators and the learners themselves can play an important role in developing materials in other languages that are not used as the main languages of teaching and learning. Class projects and authentic literacy activities in which learners from different language groups work together can be useful in the development of their multiple literacies (Giambo \& Szecsi, 2015).

Given the increasing number of linguistically diverse classrooms in South African schools, further research on how to enhance pre-service teachers' biliteracy and multiple literacies in teacher education programmes is crucial. Additionally, the content and delivery of in-service training programmes need to be explored to determine how they can contribute in supporting teachers to deal with linguistic diversity in many South African classrooms.

Finally, we recommend that teacher development (both pre- and in-service training) should prioritise teachers' own biliteracy competence (Jordaan \& Pillay, 2009) to enable them to facilitate literacy teaching across languages. Prospective and practicing teachers should not only be bilingual, but they should be biliterate and have a sound understanding of both the home language and second language literacy development in young learners (Nomlomo \& Desai, 2014). Such knowledge is crucial to enable them to enhance not only their learners' equal access to multiple literacies across languages through speech, reading and writing, but also enhance their own multilingual pedagogical practices. 


\section{REFERENCES}

AUGUST, D (Ed.). 2006. Developing literacy in second language learners: report of the National Literacy Panel on Language Minority Children and Youth. New Jersey: Lawrence Erlbaum.

BABBIE, E \& J MOUTON. 2001. The practice of social research. Cape Town: Oxford University Press Southern Africa.

BAKER, C. 2006. Foundation of bilingual education and bilingualism (4th ed.). Clevedon: Multilingual Matters.

BARTON, D \& M HAMILTON. 1998. Local literacies. New York: Routledge.

BARTON, D, M HAMILTON \& R IVANIC (Eds.). 2000. Situated literacies: reading and writing in contexts. New York: Routledge.

BAYNHAM, M. 1995. Literacy practices: investigating literacy in social contexts. London: Longman.

BLOCH, C. 2006. Theory and strategy of early literacy in contemporary Africa with special reference to South Africa. Summary paper of a cumulative $\mathrm{PhD}$ thesis presented to the Faculty of Education. Carl von Ossietzky Universitåt, Oldenburg.

BLOCH, C. 2005. Enabling effective literacy learning in multilingual South African early childhood classrooms. PRAESA Occassional Papers, 16.

BLOCH, C. 2000. Young children's literacy learning in multilingual contexts, with special reference to South Africa. In: Proceedings of Conference 2000: language and development in Southern Africa - making the right choices. NIED, Okahandja, Namibia.

BLOCH, C. 1996. Literacy in the early years: teaching and learning in multilingual early childhood classrooms. PRAESA Occassional Papers, 6.

BURCU, YM, J FANNIN, M MONTANERO \& J CUMMINS. 2014. A multilingual and multimodal approach to literacy teaching and learning in urban education: a collaborative inquiry in an inner city elementary school. Frontiers in Psychology, 5:533.

CHISHOLM, L. 2011. The challenge of South African schooling: dimensions, targets and initiatives. In Hofmeyr, J (Ed.). From inequality to inclusive growth: South Africa's pursuit of shared prosperity in extraordinary times. Rotterdam: Sense Publishers. 50-57.

CHUMBOW, BS. 2013. Mother tongue-based multilingual education: Empirical foundations, implementation strategies and recommendations for new nations. In McIIwraith, H (Ed.). Multilingual education in Africa: lessons from the Juba Language-in-Education Conference. London: British Council. 24-37.

CULICAN, SJ, S MILBURN \& C OAKLEY. 2006. Scaffolding literacy in the middle years: literacy and numeracy innovative projects initiative. Final report for round two Department of Education, Science and Training. Commonwealth of Australia.

CUMMINS, J. 2007. Promoting literacy in multilingual contexts. What works? Research into practice. Available from www.edu.gov.on.ca/eng/litercaynumeracy/ inspire/research/whatWorks.html [Accessed 8 February 2015].

CUMMINS, J, V BISMILLA, P CHOW, S COHEN, F GIAMPAPA, L LEONI, P SANDHU \& P SASTRI. 2005. Affirming identity in multilingual classrooms. The Whole Child, 63(1):3843.

DAINTE, C \& C LIGHTFOOT (Eds.). 2004. Narrative analysis: studying the development of individuals in society. Thousand Oaks: Sage.

DEPARTMENT OF BASIC EDUCATION. 2012. Curriculum and Assessment Policy Statement (CAPS) Foundation Phase Home Language Grades R-3. Pretoria: Government Printer. 
DEPARTMENT OF EDUCATION. 1997. Language in Education Policy. Government Gazette, 17997(383). Pretoria: Government Printer.

DESAI, Z. 2013. Local languages: good for the informal marketplace but not for the formal classroom? Education as Change, 17(2):193-207.

DE VOS, AS, SH STRYDOM, CB FOUCHE \& CSL DELPORT. 2005. Research at grassroots (3rd ed.). Pretoria: Van Schaik.

EDWARDS V. 1983. Language in multicultural classroom. London: Batsford.

GARCIA, O. 2009. Bilingual education in the 21st century: a global perspective. Singapore: Utopia Press.

GEE, JP. 1996. Social linguistics and literacies: ideology in discourses (2nd ed.). London: Falmer Press.

GIAMBO, D \& T SZECSI. 2015. Promoting and maintaining bilingualism and biliteracy: cognitive and biliteracy benefits and strategies for monolingual teachers. The Open Communication Journal, 9(1):56-60.

GIBBONS, P. 2002. Scaffolding language, scaffolding learning: teaching second language learners in the mainstream classroom. United States of America: Heinemann.

GLANZ, C. 2013. Why and how to invest in African languages, multilingual and multicultural education in Africa. In McIIwraith, H. (Ed.). Multilingual education in Africa: lessons from the Juba Language-in-Education Conference. London: British Council. 38-57.

GOVE, A \& P CVELICH. 2010. Early reading: igniting education for all. A report by the Early Grade Learning Community of Practice. Research Triangle Park, NC: Research Triangle Institute.

HAUKÅSA, A. 2015. Teachers' beliefs about multilingualism and a multilingual pedagogical approach. International Journal of Multilingualism. Available from http://tandfonline.com/loi/rmjm20 [Accessed 28 August 2015].

HENNING, E, W VAN RENSBURG \& B SMIT. 2004. Finding your way in qualitative research. Pretoria: Van Schaik.

HORNBERGER, NH. 2004. The continua of biliteracy and the bilingual educator: educational linguistics in practice. Bilingual Education and Bilingualism, 7(2-3):155-171.

JANSEN, J. 2008. Reflections on meaningful access to education. South African Child Gauge, 2008/2009.

JORDAAN, S \& R PILLAY. 2009. Beginning my journey of professional development: the language teacher and the teaching profession. In Ferreira, A (Ed.). Teaching language. Northlands: Macmillan South Africa. 1-10.

KERFOOT, C. \& A SIMON-VANDENBERGEN. 2015. Language in epistemic access: mobilizing multilingualism and literacy development for more equitable education in South Africa. Language and Education Special Issue, 29(3):177-185.

KENNEDY, E, E DUNPHY, B DWYER, G HAYES, T MCPHILLIPS, J MARSH, M O'CONNOR \& G SHIEL. 2012. Literacy in early childhood and primary education (3-8 years). Commissioned research report no. 15. Sheffield: University of Sheffield Educational Research Centre.

KIRKPATRICK, A. 2013. The lingua franca approach to the teaching of English: A possible pathway to genuine multilingualism in local languages and English. In McIIwraith, $\mathrm{H}$ (Ed.). Multilingual education in Africa: lessons from the Juba Language-in-Education Conference. London: British Council. 11-16. 
LATHAM, D. 2002. How children learn to write: supporting and developing children's writing in school. London: Sage.

LOWENTHAL, P \& R MUTH. 2008. Constructivism. In Provenzo, EF Jr. (Ed.). Encyclopedia of the social and cultural foundations of education. Thousand Oaks, CA: Sage.

MAKOE, P \& C MCKINNEY. 2014. Linguistic ideologies in multilingual South African suburban schools. Journal of Multilingual and Multicultural Development, 35(7):658-673.

MARTIN-JONES, M \& K JONES. 2000. Multilingual literacies: reading and writing different worlds. Amsterdam: John Benjamins.

MCIIWRAITH, H. (Ed.). 2013. Multilingual education in Africa: lessons from the Juba Language-in-Education Conference. London: British Council.

NOMLOMO, V \& Z DESAI. 2014. Reflections on the development of a pre-service language curriculum for the B.Ed. (Foundation Phase). South African Journal of Childhood Education, 4(3):87-102.

O'CARROL, S \& R HICKMAN. 2012. Narrowing the literacy gap: strengthening language and literacy development between birth and six years for children in South Africa. Cape Town: Wordworks.

OHTA, A. S. 2000. Rethinking interaction in SLA: developmentally appropriate assistance in the zone of proximal development and the acquisition of L2 grammar. In James, P (Ed.). Sociocultural theory and second language learning. New York: Oxford University Press.

PALINCSAR, SA. 1998. Social constructivist perspective on teaching and learning. Annual. Rev., 49:345-75.

PRINSLOO, M \& P STEIN. 2004. 'What's inside the box'? Children's early encounters with literacy in South African classrooms. Perspectives in Education, 22(2):67-84.

PRINSLOO, M. 2008. Children's games as local semiotic play: an ethnographic account. In Prinsloo, M \& M Baynham. Literacies, global and local. USA: John Benjamins. 117-136.

PROSPER, A. 2012. What do Grade 1 learners write? A study of literacy development at a multilingual primary school in the Western Cape. Unpublished M.Ed. thesis. Cape Town: University of the Western Cape.

REYES, I. 2006. Exploring connections between emergent biliteracy and bilingualism. Journal of Early Childhood Literacy, 6(3):267-292.

ROSKOS, KA, J CHRISTIE \& DJ RICHGELS. 2003. The essentials of early literacy instruction. Available from www.naeyc.org/resources/journal [Accessed 8 February 2015].

RUEDO, R. 2002. Second language issues in early literacy instruction. Third Annual CIERA Summer Institute. University of Southern Carlifonia: Rossier School of Education.

SAMUELS, M. 2013. The national literacy and numeracy strategy for South Africa. In McIIwraith, H (Ed.). Multilingual education in Africa: lessons from the Juba Language-inEducation Conference. London: British Council. 156-163.

SNOW, C.E. 2014. Language, literacy and the needs of the multilingual child. Perspectives in Education Special Issue, 32(1):7-16.

STREET, B., 1984. Literacy in theory and practice. Cambridge: Cambridge University Press.

STREET, B. 1993. Introduction: the new literacy studies. In Street, B (Ed.). Cross-cultural approaches to literacy. Cambridge: Cambridge University Press:1-22.

STREET, B. 1995.Social Literacies. London: Longman.

STREET, B. 2000. 'Literacy events and literacy practices': theory and practice in the new literacy studies. In Martin-Jones, M \& K Jones (Eds.). Multilingual literacies: reading and writing different worlds. Amsterdam: John Benjamins. 18-29.

Per Linguam 2016 32(3):79-94

http://dx.doi.org/10.5785/32-3-622 
STREET, B (Ed.). 2001. Literacy and development: ethnographic perspectives. London: Routledge.

TURNER, J \& K YOUB. 2005. Learning about building literacy communities in multicultural and multilingual classrooms from effective elementary teachers. Literacy Teaching and Learning, 10(1):21-41.

UNITED NATIONS EDUCATIONAL, SCIENTIFIC AND CULTURAL ORGANIZATION (UNESCO). 2006. Promoting literacy in multilingual settings. Bangkok: UNESCO.

YILMAZ, K. 2008. Constructivism: its theoretical underpinnings, variations, and implications for classroom instruction. Educational Horizons, 86(3):161-172.

\section{BIOGRAPHICAL NOTES}

Ancyfrida Prosper holds an M.Ed. degree from the University of the Western Cape. She is the Director of the Mwanza Regional Centre and a lecturer in the Institute of Continuing Education at the Open University of Tanzania, where she is currently registered for PhD. Her research interest lies in early literacy and applied linguistics.

Vuyokazi Nomlomo is an Associate Professor in the Language Education Department at the University of the Western Cape. Her research interests are in language education, with a special focus on language policy issues, mother tongue and multilingual education. Her research also focuses on early literacy, sociolinguistics, African language studies and teacher education. 